mittent regimens. Meanwhile we feel unable to continue to use rifampicin at a dose of $1,200 \mathrm{mg}$ twice-weekly.

We acknowledge the expert technical help of Miss Eleanor Lloyd and Mrs. Irene Owen, and the constructive suggestions of Professor D. A. Mitchison and Professor J. V. Dacie, Miss Angela Hartog and Miss Margaret Oliver helped with the collection of clinical data. The medical staffs of the Willesden Chest Clinic, the Central Middlesex Hospital, St. Charles's Hospital, and the Brompton Hospital kindly gave permission for patients under their care to act as controls. Dr. M. A. Thomson collected most of the control samples. Dr. M. A. Blajchman helped considerably with the early investigations. Miss P. Gammon estimated the actual content of the rifampicin solution. Lepetit Pharmaceuticals Ltd. generously supplied the rifampicin and a grant for technical assistance. Drs. Bergamini and Granger, of Lepetit Ltd., provided much valuable information.

\section{References}

Batten, J. (1969). Tubercle, 50, 294.

Blajchman, M. A., Lowry, R. C., Pettit, J. E., and Stradling, P. (1970). British Medical fournal, 3, 24.

Burghard, G., and Petitjean, R. (1970). Fournal de Medicine de Strasbourg, 1, 79.
Canetti, G., Le Lirzin, M., Porven, G., Rist, N., and Grumbach, F. (1968). Tubercle, 49, 367

Croft, J. D., et al. (1968). Annals of Internal Medicine, 68, 176.

Dacie, J. V., and Lewis, S. M. (1968). Practical Haematology, 4th ed. London, Churchill.

Dacie, J. V., and Worlledge, S. M. (1969). Progress in Hematology, 6, 82.

Decroix, G., et al. (1969). Revue de la Tuberculose et de Pneumologie, 33, 751

Dickinson, J. M., and Mitchison, D. A. (1970). Tubercle, 51, 82.

Doyle, J. A., et al. (1969). In XX International Tuberculosis Conference, New York, p. 25. New York, Excerpta Medica.

Farga, V. (1970). Personal communication.

Grumbach, F., Canetti, G., and Le Lirzin, M. (1969). Tubercle, 50, 280.

Grumbach, F., Canetti, G., and Le Lirzin, M. (1969). Tubercle, 50, 280.

Gyselen, A., et al. (1969). Acta Tuberculosea et Pneumologica Belgica, 60, 563.

Harris, J. W. (1956). Fournal of Laboratory and Clinical Medicine, 47, 760

Larbaoui, D., et al. (1970). Revue de la Tuberculose et de Pneumologie, 34, 559.

Lees, A. W., Asgher, B., Hasham, M. A., and Sinhar, B. N. (1970). British Fournal of Diseases of the Chest, 64, 90 .

Lesobre, R., Ruffinn, J., Teyssier, L., Achard, F., and Brefort, G. (1969). Revue de la Tuberculose et de Pneumologie, 33, 393.

Polansky, F. (1970). Bulletin of the International Union against Tuberculosis, 43, 295.

Poole, G. W., and Stradling, P. (1965). Tubercle, 46, 290.

Poole, G. W., and Stradling, P. (1969). British Medical fournal, 1, 82.

Ramakrishnan, C. V., et al. (1969). Tubercle, 50, 115.

Stradling, P., and Poole, G. W. (1970). Tubercle, 51, 44

Svejgaard, A., Kjerbe, K. E., and Kissmeyer-Nielsen, F. (1967). In Histocompatibility Testing, ed. E. S. Curtoni, P. L. Mattinz, and R. M. Tosi. Compatibility Testing, ed. E.

Tuberculosis Chemotherapy Centre, Madras. (1964). Bulletin of the World Health Organization, 31,247 Verbist, L., and Gyselen, A. (1968). American Review of Respiratory Diseases,
98, 923 .

\title{
Effects of Poisoning on Serum Enzyme Activities, Coagulation, and Fibrinolysis
}

\author{
N. WRIGHT, A. R. CLARKSON, S. S. BROWN, V. FUSTER
}

British Medical fournal, 1971, 3, 347-350

\section{Summary}

Prolonged coma due to acute overdosage with hypnotic drugs is shown to be associated with a pronounced increase in the activity of serum creatine kinase and in the concentration of fibrin degradation products and with less pronounced abnormalities of other serum enzymes and of other indices of coagulation and fibrinolysis. Evidence is presented that skeletal muscle damage occurs and that this is related to the coagulation abnormality. These findings probably explain some of the non-specific features such as fever which commonly occur in recovery from severe poisoning.

\section{Introduction}

Elevation of certain serum enzyme activities is commonly associated with cellular damage. In poisoned patients (Brown et al., 1970) such changes may reflect specific organ damage due to drug toxicity or tissue injury which has been attributed to hypothermia (Maclean et al., 1968) or tissue hypoxia (Mandy

\section{Royal Infirmary, Edinburgh EH3 9YW}

N. WRIGHT, B.SC., M.R.C.P.ED., Medical Registrar, Regional Poisoning

A. R. CLARKSON, M.R.A.C.P., Research Fellow, Medical Renal Unit, Department of Medicine

S. S. BROWN, PH.D., Senior Lecturer, University Department of Clinical

V. FUSTER, M.D., Research Fellow, Edinburgh and South-East Scotland Regional Blood Transfusion Centre and Ackerman, 1970). As abnormalities in coagulation and fibrinolysis may play a part (Clarkson et al., 1970) in the development of renal damage in acute ischaemic renal failure, it seemed possible that similar mechanisms might contribute to tissue injury in poisoned patients. Accordingly, a study was undertaken of deeply unconscious poisoned patients whose recovery was not complicated by renal dysfunction. Changes in serum enzyme activities were correlated with abnormalities of coagulation and fibrinolysis and with clinical features.

\section{Patients and Methods}

The study was limited to patients who developed grade IV coma (Matthew and Lawson, 1970) after overdosage of hypnotic or tricyclic antidepressant drugs. The time of ingestion was determined as carefully as possible from the history, and the duration of coma was defined as the period between this time and that when the patient responded to loud vocal commands. All patients were treated by conservative supportive therapy and intensive nursing care, and particular attention was paid to monitoring pulse rate, blood pressure, rectal temperature, minute volume as measured by a Wright's spirometer, respiratory rate, and to the electrocardiogram. Patients at risk of aspirating were intubated. Positive-pressure ventilation was instituted if the minute volume was less than 4 litres or if arterial blood gas analysis indicated that there was serious impairment of gas exchange. Hypotension (systolic blood pressure $<80 \mathrm{~mm} \mathrm{Hg}$ ) was treated with metaraminol $(2.5 \mathrm{mg}$ intramuscularly); if this was ineffective plasma expanders were infused according to central venous pressure readings. No active measures to remove poisons were instituted except in one patient (Case 18, Table I) who was haemodialysed. 
Serum alanine transaminase (GPT), aspartate transaminase (GOT), 2-hydroxybutyrate dehydrogenase (HBD), and lactate dehydrogenase $(\mathrm{LDH})$ were assayed daily by reaction rate analyser methods (Smith, Brown, and Taylor, 1970), creatine kinase (CK) by recording spectrophotometry with creatine phosphate as substrate (Smith, MacFie, and Oliver, 1970), and amylase by a starch-iodine method. Drug determinations were carried out by appropriate spectrophotometric or gas chromatographic methods.

Daily estimations were also made of serum and urinary fibrin/fibrinogen degradation products (F.D.P.) (Merskey et al., 1966), plasma fibrinogen (Ellis and Stransky, 1961), plasma soluble fibrin monomer complexes (S.F.M.C.) (Lipinski and Worowski, 1968), euglobulin lysis time (E.L.T.) (Cash and Leask, 1967), and platelet factor 4 (P.F.4) using a modification of the method of Poplawski and Niewiarowski (1965). Plateletpoor plasma heated to $60^{\circ} \mathrm{C}$ for 10 minutes was assayed in a clotting system of test plasma, pooled human plasma, heparin, and thrombin. The clotting time obtained was expressed as a percentage of a control in which distilled water was substituted for the test plasma.

\section{Results}

Table I summarizes the relevant clinical and toxicological data on each patient. None of the cases were fatal, but the clinical recovery of those who were comatose for long periods was accompanied by fever, hyperpnoea, leucocytosis, and increased erythrocyte sedimentation rate. The onset and duration of these abnormalities closely followed the biochemical changes detailed below. Only in five such patients, however, were these features associated with clinical and bacteriological evidence of infection. There were no electrocardiographic abnormalities except in one patient (Case 8) who showed transient J waves and in one (Case 10) in whom atrial fibrillation was present throughout. Assessment of fluid balance and of plasma urea and creatinine concentrations provided no evidence of renal failure in any patient.

On the basis of changes in serum enzyme activities and coagulation indices the patients were considered in two groups (Table I, A and B). Those of group A showed no abnormalities in any of the respects whereas those of group $B$ developed changes (Tables II and III) which were maximal on the second or third days. The most significant alterations occurred in serum creatine kinase and F.D.P. (Fig. 1); less significant changes, following a similar time sequence, were observed in serum alanine transaminase, plasma soluble fibrin monomer complexes and platelet factor 4 . There were only small changes in the mean levels of serum aspartate transaminase and hydroxybutyrate and lactate dehydrogenases, plasma fibrinogen, and plasminogen activator content, and none at all of serum amylase. In individual cases, however, more pronounced changes in plasma fibrinogen and plasminogen activator content were sometimes found. Urinary F.D.P. were not found in the patients of group A, but were detected in 12 patients of group B

TABLE I-Principal Clinical and Toxicological Data

\begin{tabular}{|c|c|c|c|c|c|c|c|c|c|c|c|}
\hline \multirow{2}{*}{$\begin{array}{l}\text { Case } \\
\text { No. }\end{array}$} & \multirow{2}{*}{$\begin{array}{l}\text { Age } \\
\text { and } \\
\text { Sex }\end{array}$} & \multirow{2}{*}{$\begin{array}{l}\text { Drug Ingested and } \\
\text { Blood Level (mg/100ml) } \\
\text { on Admission* }\end{array}$} & \multirow{2}{*}{$\begin{array}{c}\text { Hours } \\
\text { between } \\
\text { Ingestion } \\
\text { and Admission }\end{array}$} & \multirow{2}{*}{$\begin{array}{l}\text { Depth (Grade } \\
\text { on Admission) } \\
\text { and Duration } \\
\text { (hr) of Coma }\end{array}$} & \multicolumn{2}{|c|}{$\begin{array}{l}\text { Blood Pressure } \\
(\mathrm{mm} \mathrm{Hg})\end{array}$} & \multicolumn{3}{|c|}{$\begin{array}{c}\text { Temperature } \\
\left({ }^{\circ} \mathrm{C}\right)\end{array}$} & \multirow{2}{*}{ Therapy } & \multirow{2}{*}{ Complications } \\
\hline & & & & & \begin{tabular}{|c|} 
On \\
Admission
\end{tabular} & Lowest & \begin{tabular}{c|} 
On \\
Admission
\end{tabular} & Lowest & Highest & & \\
\hline
\end{tabular}
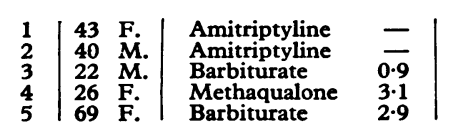

2
$\mathbf{4}$
3
5
3
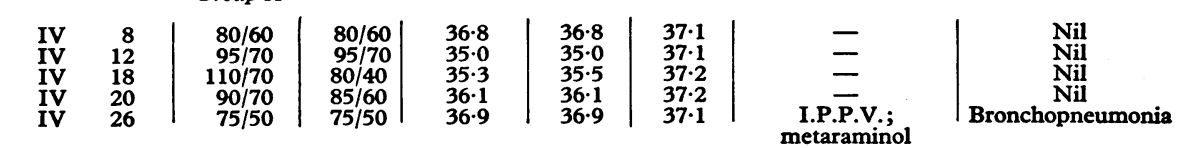

Group B
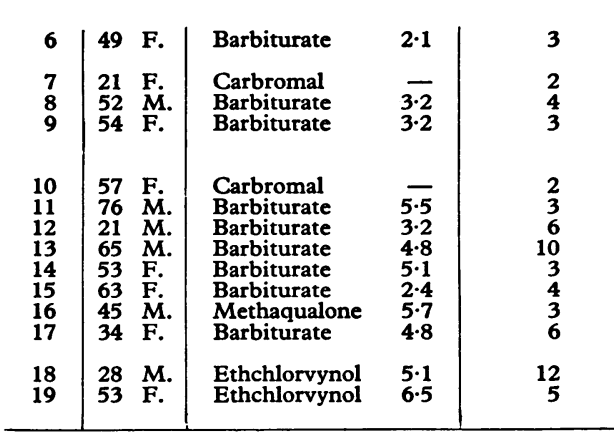

\begin{tabular}{|l|}
$60 / 40$ \\
$90 / 60$ \\
$75 / 50$ \\
$45 / 20$ \\
\\
$90 / 60$ \\
$70 / 50$ \\
$90 / 50$ \\
$70 / 50$ \\
$90 / 60$ \\
$90 / 60$ \\
$80 / 50$ \\
$60 / 40$ \\
$90 / 60$ \\
$90 / 70$ \\
\hline
\end{tabular}

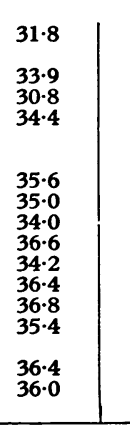

Metaraminol; $\mid$ Bronchopneumonia plasma expanders \begin{tabular}{l|l} 
I.P.P.V. & Nil \\
I.P.
\end{tabular} I.P.P.V.;
Bronchopneumonia metaraminol; plasma expanders $\quad$ Nil \begin{tabular}{c|c}
$\begin{array}{c}\text { Metaraminol } \\
\text { Metaraminol } \\
\text { I.P.P.V. }\end{array}$ & $\begin{array}{c}\text { Nil } \\
\text { Bronchopneumonia } \\
\text { Nil }\end{array}$ \\
Bronchopneumonia
\end{tabular} I.P.P.V.V. I.P.P.V.; metaraminol Nil Nil
Bronchopneumonia Nil Nil Nil

Where the blood level was not measured qualitative analysis of urine confirmed the diagnosis.

TABLE II-Sequence of Mean Serum Enzyme Activities in Cases 6-19

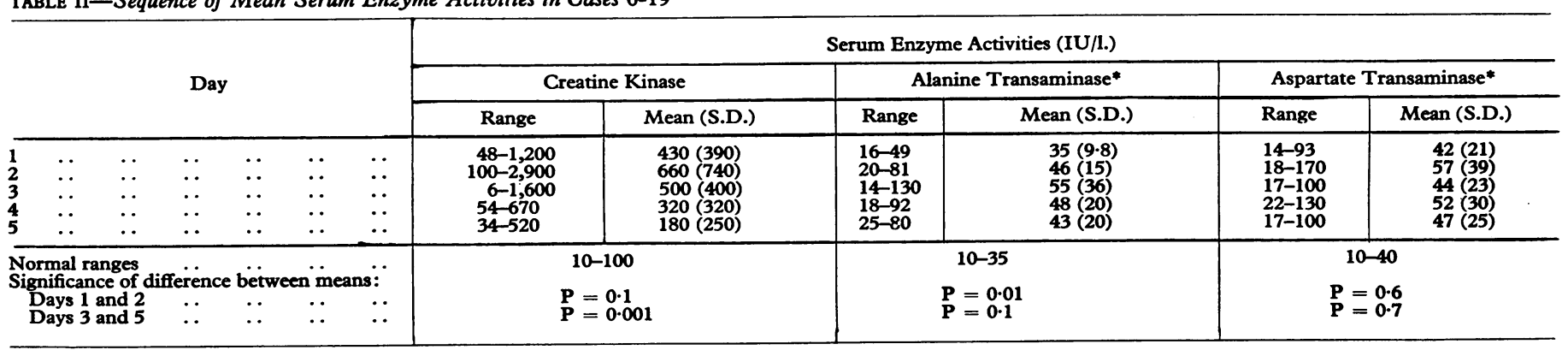

-Excluding Case 9 whose serum aspartate and alanine transaminases reached peak levels of 410 and 350 IU/1. respectively on day 3. 
TABLE III-Sequence of Mean Coagulation Indices in Cases 6-19

\begin{tabular}{|c|c|c|c|c|c|c|c|c|c|c|c|c|c|c|}
\hline & & \multicolumn{4}{|c|}{ Day } & \multicolumn{2}{|c|}{$\begin{array}{c}\text { Fibrin/Fibrinogen } \\
\text { Degradation Products } \\
(\mu \mathrm{g} / \mathrm{ml})\end{array}$} & \multicolumn{2}{|c|}{$\begin{array}{l}\text { Plasma Fibrinogen } \\
(\mathrm{mg} / 100 \mathrm{ml})\end{array}$} & \multicolumn{2}{|c|}{$\begin{array}{l}\text { Plasminogen Activator } \\
\text { Content } \\
\text { (Activator Units) }\end{array}$} & \multicolumn{2}{|c|}{$\begin{array}{c}\text { Soluble Fibrin } \\
\text { Monomer Complexes } \\
\text { (O.D. units) }\end{array}$} & \multirow{2}{*}{$\begin{array}{c}\begin{array}{c}\text { Platelet Factor } \\
\mathbf{4} \\
(\%)\end{array} \\
\text { Range }\end{array}$} \\
\hline & & & & & & Range & Mean (S.B.) & Range & Mean (S.D.) & Range & Mean (S.D.) & Range & Mean & \\
\hline $\begin{array}{l}1 \\
2 \\
3 \\
4 \\
5 \\
\end{array}$ & $\begin{array}{l}\cdots \\
\cdots \\
\cdots \\
\ldots\end{array}$ & $\begin{array}{l}\cdots \\
\cdots \\
\cdots \\
\cdots \\
\end{array}$ & $\begin{array}{l}\ldots \\
\cdots \\
\cdots \\
\cdots\end{array}$ & $\begin{array}{l}\cdots \\
\because \\
\cdots \\
\cdots\end{array}$ & $\begin{array}{l}. \\
\because \\
\because \\
\cdots \\
\end{array}$ & $\begin{array}{r}4 \cdot 5-25 \\
4 \cdot 8-50 \\
14-49 \\
8 \cdot 0-74 \\
4 \cdot 8-33 \\
\end{array}$ & $\begin{array}{l}11(12) \\
25(28) \\
26(27) \\
23(29) \\
14(16) \\
\end{array}$ & $\begin{array}{l}270-640 \\
220-1030 \\
320-1030 \\
300-1170 \\
350-1140 \\
\end{array}$ & $\begin{array}{l}430(150) \\
560(600) \\
700(720) \\
620(660) \\
640(700) \\
\end{array}$ & $\begin{array}{l}12-18 \\
1 \cdot 5-9 \cdot 0 \\
3 \cdot 1-8 \cdot 6 \\
2 \cdot 1-13 \\
4 \cdot 4-13 \\
\end{array}$ & $\begin{array}{l}15(15) \\
5 \cdot 3(5 \cdot 5) \\
5.5(5 \cdot 4) \\
6 \cdot 0(6.4) \\
8 \cdot 3(8 \cdot 7)\end{array}$ & $\begin{array}{l}0.55-0.91 \\
0.54-1.15 \\
0.65-1.16 \\
0.69-1.13 \\
0.70-1.30\end{array}$ & $\begin{array}{l}0.76 \\
0.87 \\
1.01 \\
0.93 \\
0.94\end{array}$ & $\begin{array}{c}64-94 \\
92-125 \\
101-120 \\
68-120 \\
66-96\end{array}$ \\
\hline \multicolumn{3}{|c|}{$\begin{array}{l}\text { Normal ranges } \\
\text { Significance of } d \\
\text { Days } 1 \text { and } 3 \\
\text { Days } 3 \text { and } 5\end{array}$} & $\begin{array}{l}\ldots \\
\text { ffere } \\
\ldots \\
\ldots\end{array}$ & $\begin{array}{l}\text { bet } \\
\cdots \\
\cdots\end{array}$ & $\begin{array}{c}\ldots \\
\text { en means: } \\
\ldots\end{array}$ & \multicolumn{2}{|c|}{$\begin{array}{l}1-20 \\
=0.001 \\
=0.002\end{array}$} & \multicolumn{2}{|c|}{$\begin{array}{l}150-450 \\
P=0.2 \\
P=0.6\end{array}$} & \multicolumn{2}{|c|}{$\begin{array}{l}- \\
=0.05 \\
=0.7\end{array}$} & \multicolumn{2}{|c|}{$\begin{array}{l}0.48-0.68 \\
P=0.01 \\
P=0.6\end{array}$} & $\begin{array}{c}87-113 \\
P=0.02 \\
P=0.01\end{array}$ \\
\hline
\end{tabular}
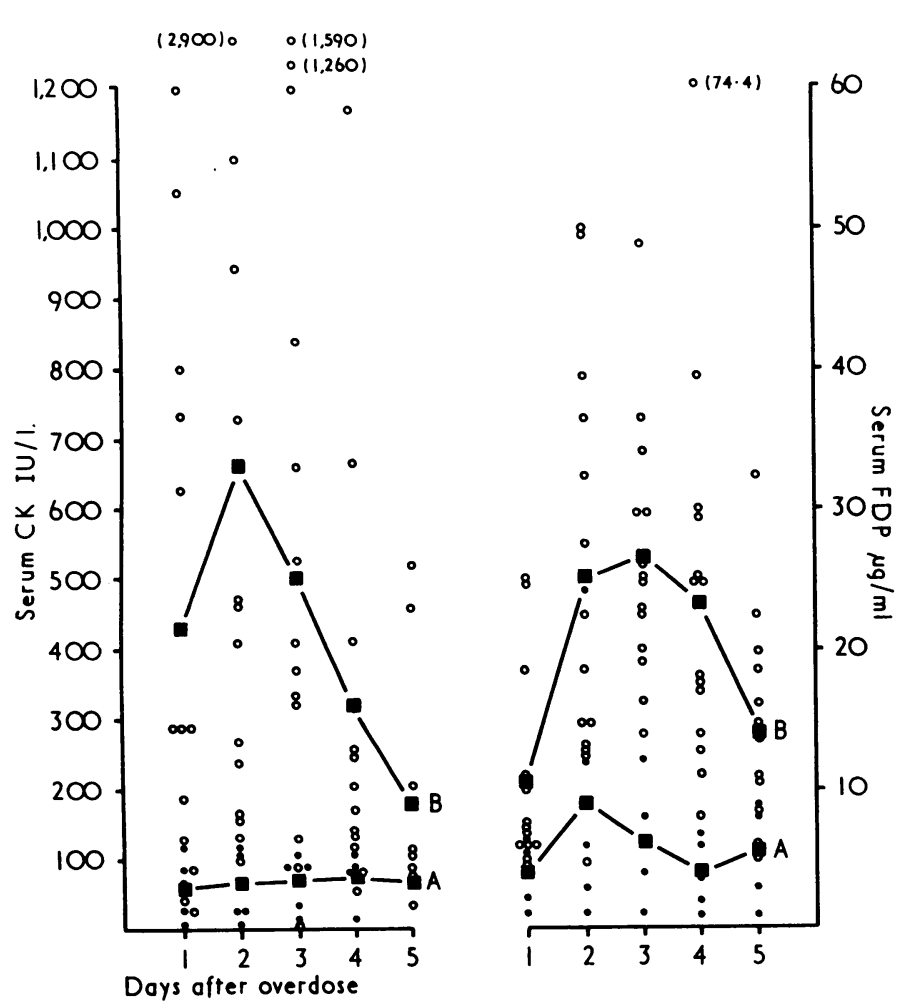

FIG. 1-Daily values of the activity of serum creatine kinase and of the concentration of plasma fibrin/fibrinogen degradation products for Cases 1-5 (Table I, group A; closed circles). The daily means for the two groups are indicated by squares. Normal ranges are shown in Tables II and III.

between the second and fourth days. The overall pattern of enzyme and coagulation changes for a typical patient of group B is shown in Fig. 2.

\section{Discussion}

This report describes changes in serum enzyme activities, and in coagulation and fibrinolytic indices, in a group of patients who developed deep coma after acute overdosage with hypnotic drugs. The pattern of these changes strongly suggests that they occur independently of the particular drug ingested. These abnormal findings were almost wholly confined to patients unconscious for more than 30 hours. In a group of patients who were comatose for shorter periods no significant enzyme or coagulation changes were found.

The enzyme assays were selected to give positive indications of specific or generalized tissue damage. Serum amylase estimations were systematically performed because of the possibility of injury to the pancreas such as occasionally occurs in carbon monoxide poisoning (Brown et al., 1970) and in hypothermia
(Duguid et al., 1961); this enzyme, however, was not raised in any patient of the present series. In patients unconscious for long periods there were large and rapid rises in serum creatine kinase activity accompanied in general by only marginal increases in the activities of the serum transaminases and dehydrogenases.

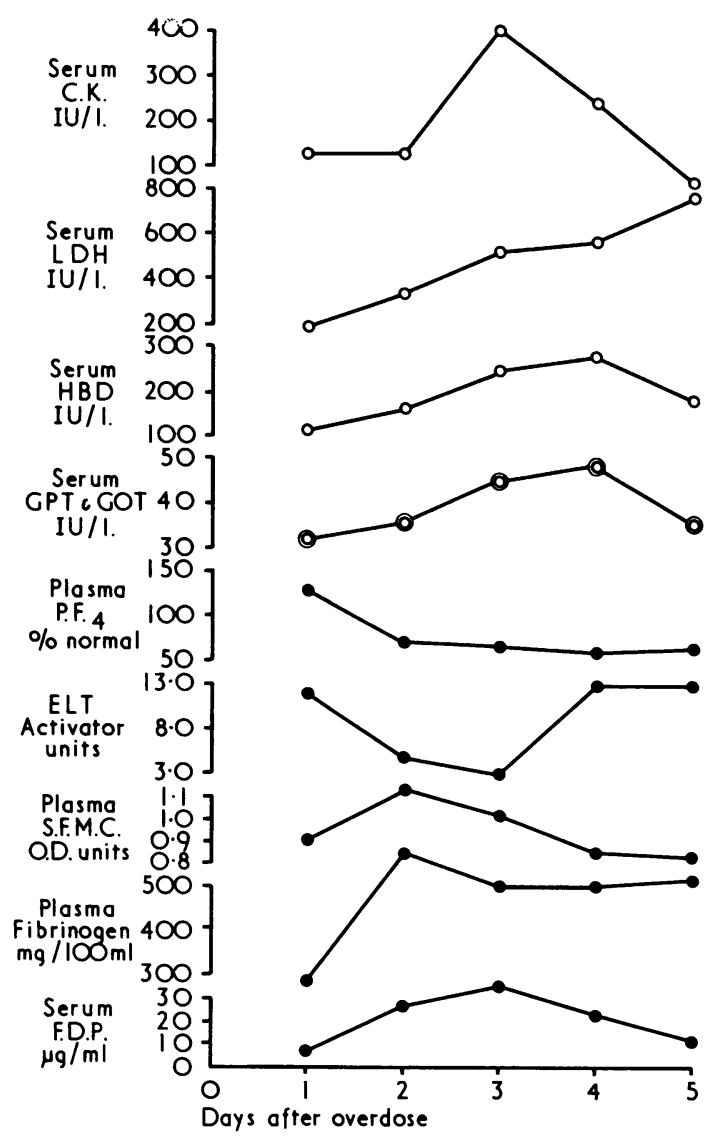

FIG. 2-Daily values of enzyme activities and coagulation and fibrinolytic indices for Case 15 (Table I). Normal ranges for LDH and HBD are 100-400 and 100-240 IU/1. respectively. Other normal ranges are shown in Tables II and III.

Studies of the creatine kinase isoenzyme patterns in these patients (A. F. Smith, personal communication) support the view that these large rises in serum creatine kinase activity are consistent with injury to the skeletal musculature (Wilkinson, 1970). In previous case reports of poisoned patients (Maclean et al., 1968; Henderson et al., 1970) concurrent impairment of cardiac or renal function complicated the interpretation of 
rises in serum creatine kinase activity. In the present series, however, there was no clinical, biochemical, or electrocardiographic evidence that hepatic, renal, or cardiac damage occurred.

The present study confirms previous reports that fever may occur without infection in hypnotic overdosage, as positive signs of infection could be found in only 5 out of 14 patients with fever. It has been proposed (Reed et al., 1952) that barbiturate causes such a disorder by an action on the hypothalmic centre, but this remains unproved. Alternatively, pathological changes in sweat glands leading to skin blistering could contribute to temperature variations (Leavell, 1969). However, skin involvement occurs in only $5 \%$ of all barbiturate intoxications (Beveridge and Lawson, 1965); it is not confined to grade IV coma and was not apparent in any patient in the present series. More likely fever is a consequence of generalized tissue injury, particularly to skeletal muscle, as the onset and duration of fever corresponded to the time course of the biochemical changes described. Whatever the cause, a strong case is presented here against the indiscriminate use of antibiotics in the recovery phase of drug overdosage and for caution in the interpretation of enzyme findings. In most cases muscle injury is subclinical and recognized only by a rise in serum creatine kinase activity. In severe poisoning, however, muscle pain and eventual calcification of necrotic muscle fibres may occur (Clark and Sumerling, 1966). It is noteworthy that fever, hyperventilation, leucocytosis, and raised erythrocyte sedimentation rate commonly accompany illness in which there is evidence of intravascular coagulation. That this may also occur in severe poisoning is suggested by the observed rises in serum F.D.P. and in plasma platelet factor 4, soluble fibrin monomer complexes, and fibrinogen. The decrease in plasminogen activator content perhaps reflects increased utilization or may indicate decreased release from a large source such as muscle veins.

The close parallel between enzyme and coagulation changes raises the question of cause and effect. It seems unlikely that hypothermia (Maclean et al., 1968) is wholly responsible for the enzyme changes, as pronounced rises were found in patients who were at no time hypothermic. If tissue hypoxia (Maclean et al., 1968) accompanying hypotension was a causative factor a rapid rise in serum enzyme activities might be expected on improvement of the peripheral circulation, but in this study such improvement clearly preceded the enzyme changes. Thus though hypothermia, hypotension, and hypoxia may be contributory they are unlikely to be entirely responsible for the observed changes.

A key event may be fibrin deposition throughout the microcirculation, which gives rise to ischaemic end-organ damage with the release of intracellular enzymes. Alternatively, enzyme release may activate platelet aggregation and potentiate fibrin deposition (Meltzer, 1971) and thus impair the microcirculation.
Though there is no evidence to bear on either of these hypotheses at present, enzyme release may be related in some way to abnormal coagulation and fibrinolysis.

Similar coagulation changes occur in other situations of acute stress, such as myocardial infarction (Chakrabarti et al., 1969), postpartum (Bonnar et al., 1970), severe trauma and burns (Innes and Sevitt, 1964), and major surgery (Ruckley et al., 1970). It is in these circumstances that acute renal failure and deep vein thrombosis most commonly occur, and metabolic changes such as those reported here may predispose to these complications.

We are grateful to Dr. Henry Matthew for permission to study patients under his care, and to Drs. J. S. Robson and J. D. Cash for advice and encouragement.

This investigation was supported by grants from the South-Eastern Regional Hospital Board, Scotland, and Roussel Laboratories Ltd. (to S.S.B.), and the Winston Churchill Memorial Trust of Australia and the Scottish Home and Health Department (to A.R.C.). V.F. was a fellow of the Juan March Foundation of Spain.

\section{References}

Beveridge, G. W., and Lawson, A. A. H. (1965). British Medical fournal, 1,835 .

Bonnar, J., McNicoll, G. P., and Douglas, A. S. (1970). British Medical fournal, 2, 200.

Brown, S. S., Proudfoot, A. T., Raeburn, J. A., and Wright, N. (1970). In Proceedings of the 7th International Congress of Clinical Chemistry, vol. 2, p. 173. Basel, Karger.

Cash, J. D., and Leask, E. (1967). Journal of Clinical Pathology, 20, 209.

Chakrabarti, R., Hocking, E. D., and Fearnley, G. R. (1969). fournal of Clinical Pathology; 22, 659.

Clark, J. G., and Sumerling, M. D. (1966). Britich Medical fournal, 2, 214.

Clarkson, A. R., MacDonald, M. K., Fuster, V., Cash, J. D., and Robson, J. S. (1970). Quarterly fournal of Medicine, 39, 585 .

Duguid, H., Simpson, R. G., and Stowers, J. M. (1961). Lancet, 2, 1213.

Ellis, B. C., and Stransky, A. (1961). Fournal of Laboratory and Clinical Medicine, $58,477$.

Henderson, L. W., Metz, M., and Wilkinson, J. H. (1970). British Medical fournal, 3,751 .

Innes, D., and Sevitt, S. (1964). Fournal of Clinical Pathology, $17,1$.

Leavell, U. W. (1969). Archives of Dermatology, 100, 218.

Lipinski, B., and Worowski, K. (1968). Thrombosis et Diathesis Haemorrhagica, 20, 44.

Maclean, D., Griffiths, P. D., and Emslie-Smith, D. (1968). Lancet, 2, 1266.

Mandy, S., and Ackerman, A. B. (1970) fournal of American Medical Association, 213, 253.

Matthew, H., and Lawson, A. A. H. (1970). Treatment of Common Acute Poisonings, 2nd edn. Edinburgh, Livingstone.

Meltzer, H. (1971). Lancet, 1, 918 .

Merskey, C., Kleiner, G. J., and Johnson, A. J. (1966). Blood, 28, 1.

Poplawski, A.. and Niewiarowski, S. (1965). Thrombosis et Diathesis Haemorrhagica, 13, 149.

Reed, C. E., Driggs, M. F., and Foote, C. C. (1952). Annals of Internal Medicine, 37, 290.

Ruckley, C. V., et al. (1970). British Medical fournal, 4, 395.

Smith, A. F., Brown, S. S., and Taylor, R. (1970). Clinica Chimica Acta,

30, 105.

Wilkinson, J. H. (1970). Isoenzymes, 2nd edn. London, Chapman and Hall. 